\title{
Struktur Fungsional pada Pribahasa Indonsia Tinjauan Sintaksis
}

\author{
Hanana Muliana ${ }^{1}$ \\ Muhammad Dahlan²

\begin{abstract}
12Prodi Pendidikan Bahasa dan Sastra Indonsia Fakultas Keguruan dan Ilmu Pendidikan Universitas Muhammadiyah Makassar
\end{abstract}

1hanana@unismuh.ac.id

2muhdahlan@unismuh.ac.id

\begin{abstract}
Abstrak
Penelitian ini bermanfaat buat menarangkan wujud fungsional kalimat pribahasa bahasa Indonesia. Tujuan dari penelitian ini yakni wujud fungsional kalimat dalam peribahasa bahasa Indonesia. Metode pengumpulan informasi dalam penelitian ini memakai tata cara kepustakaan, rujukan, serta catat. Metode analisis informasi yang digunakan dalam penelitian ini yakni tata cara yang tidak berubah- ubah dengan metode dasar serta tata cara pemilahan determinan( PUPs). Berdasarkan data dari hasil penelitian yang telah dipaparkan, beberapa pribahasa ditinjau dari segi linguistik sintaksis yakni dengan bentuk subjek+Predikat terdapat empat kalimat, bentuk subjek+keterangan terdapat enam kalimat, bentuk subjek+predikat+objek terdapat tiga kalimat, bentuk subjek+predikat+keterangan terdapat satu kalimat, bentuk predikat+subjek+keterangan terdapat lima kalimat, bentuk predikat+keterangan terdapat tiga kalimat, subjek+predikat+pelengkap terdapat dua kalimat, bentuk
\end{abstract} Subjek+predikat+pelengkap+keterangan terdapat satu kalimat.

Kata kunci :Bentuk Fungsional, Pribahasa, Sintaksis

\section{Pendahuluan}

Kehidupan masyarakat atau manusia saat ini sangat erat kaitannya dengan bahasa kerena ketika mereka saling berinteraksi akan menggunakan bahasa sebagai alatnya. Penggunaan biasa terbagi menjadi beberapa poin pokok yakni sebagai iktikad, dalam bentuk komentas, gagasan, ide, dan lainnya. Dengan demikian, guna bahasa yang sangat utama yakni selaku fasilitas komunikasi manusia. Dalam berbicara digunakan bahasa selaku media buat mengantarkan data. Orang yang menggunakan bahasa dan memang menjadi pengguna bahasa sangat berpengaruh besar ketika menggunakan bahasa tersebut. Kajian bahasa dibahasa lengkap melalui linguistik yang luas atau universal. Ada beberapa pembagian linguistik universal yakni tataran fonologi, tataran morfologi, tataran sintaksis, dan tataran semantik. Salah satu konsumsi fasilitas komunikasi berbentuk bahasa tulis yakni pribahasa indonsia.

Pribahasa yakni ungkapan ataupun kalimat- kalimat ringkas ataupun padat namun memiliki arti meluas adapun yakni segi membandingkan, sebuah amanat, tujuan hidup, dan perilaku yang memiliki aturan. Munculnya pribahasa berawal dari mulut ke mulit atau generasi ke generasi yang biasanya berisi pengalaman, kejadian, dan masyarakat yang mengamatinya. 
Wujud fungsional kalimat yakni lapisan bangun kalimat yang terdiri atas unsurunsur kalimatyang mempunyai ataupun menduduki guna tertentu dalam sesuatu kalimat. Analisis fungsional didasarkan atas guna S (subjek), P (predikat), 0 (objek), Pel (aksesoris), serta K (penjelasan). Faktor fungsional tidak senantiasa muncul bertepatan. Faktor yang cenderung senantiasa terdapat dalam klausa yakni P (aksesoris), sebaliknya faktor yang lain bisa jadi terdapat, bisa jadi pula tidak (Ramlan, 1996: 91).

Penelitian juga sejalan dengan dengan penelitian yang dilakukan sebelumnya oleh Fitria Nurkholis (2012) dengan judul Ragam sertaBentuk Fungsional Kalimat pada Terjemahan Al-Quran Surah Al-Lail. Yang menyatakan bahwa kalimat-kalimat dalam terjemahan Al-Quran memiliki bentuk yang tidak sejalan dengan bentuk fungsional kalimat bahasa indonsia yang lazimnya berbentuk SPOK.

Senada dengan penelitian Taufiq Hidayat (2012) dalam penelitiannya yang berjudul "Analisis Struktur Fungsional dan Ragam Kalimat pada Terjemahan Surah AnNaba". Hasil penelitiannya adalah terjemahan Surah An-Naba terdapat 25 pola kalimat: 1) pola kalimat objek-subjek-predikat (O-S-P), 2) pola kalimat $S$ Konj $P, 3$ ) pola kalimat Konj OSP, 4) pola kalimat Pel Ktw SP, 5) pola kalimat SPO Pel, 6) pola kalimat Konj SP, 7) pola kalimat Konj SP Ket, 8) pola kalimat Konj SPO Pel, 9) pola kalimat Konj SPO Ket, 10) pola kalimat SP Ket, 11) pola kalimat SP, 12) pola kalimat Ket SP, 13) pola kalimat Konj SP Ket, 14) pola kalimat PO ket, 15) pola kalimat SP Ket 16) pola kalimat PO Ket 17) pola kalimat SP Ket 18) pola kalimat SP Ket Konj Pel, 19) pola kalimat SPO Konj O Ket SPO 20) pola kalimat SP Konj Pel, 21) pola kalimat Ket SP, 22) pola kalimat Konj SPO, 23) pola kalimat SP SPO, 24) pola kalimat S Konj P, 25) pola kalimat SPO, kalimat dengan pola Ket SPO Ket kalimat yang berpolakan Ket SP SP SPO Pel, kalimat yang berpolakan SPO SP SPO Pel. Dalam terjemahan Surah An-Naba ditemukan tiga jenis kalimat. Ketiga jenis kalimat tersebut adalah: kalimat berita, kalimat tanya, dan kalimat perintah. Ketiga jenis kalimat tersebut tersebar di dalam terjemahan Surah An-Naba

Bersumber pada penjelasan di atas, penulis tertarik buat menganalisis wujud fungsional yang ada pada pribahasaindonsia. Oleh karena itu, penelitianialah" BentukFungsional pada Pribahasaindonsia: Tinjauan Sintaksis".”.

\section{Kajian Teori}

Susunan bahasa yang sistem satuan-satuannya titik terbesar ada pada kata serta saling kohesi dan koherensi lainnya hal ini merupakan pendapat dari Kridalaksana (2002) (dalam Khairah dan ridwan 2015). Menurut Chaer (2009), sintaksis ialah subsistem kebahasaan yang membicarakan penataan sertapengaturan kata-kata itu kedalam satuan-satuan yang lebih besar yang disebut satuan sintaksis, yakni kata, frasa, klausa, kalimat sertawacana. Menurut Kridalaksana (2002) fungsi sintaksis ada lima, yakni subjek (S), predikat (P), objek (O), komplemen (Komp), sertaketerangan (Ket). Dari kelima fungsi tersebut, tidak semuanya harus hadir dalam suatu kalimat.Fungsi sintaksis yang harus hadir hanya subjek sertapredikat, sedangkan objek, komplemen, sertaketerangan, tidak wajib ada.

Menurut Kridalaksana (2002) (dalam Nur Azizah dan Faridah 2010) Pribahasa ialah ungkapan yang walaupun tidak langsung namun secara tersirat menyampaikan suatu hal yang dapat dipahami oleh pendengarnya atau pembacanya karena sama-sama hidup dalam ruang lingkup budaya yang sama. Adapun menurut Manaf (2009) Pribahasa dapat 
dibedakan menjadi dua jenis, yakni pribahasa yang memiliki arti lugas sertapribahasa yang memiliki arti simbolis. Pribahasa yang memiliki arti lugas terdiri dari dua jenis, yakni bidal serta pepatah, sedangkan pribahasa yang memiliki arti simbolis, yakni perumpamaan.

Arifin dan Tasai (2008: 66) berpendapat bahwa kalimat adalah satuan bahasa terkecil, dalam wujud lisan atau tulisan, yang mengungkapkan pikiran yang utuh. Sekurang-kurangnya kalimat dalam ragam resmi baik lisan dan tulisan harus memiliki subjek dan predikat.

Berdasarkan beberapa pendapat para ahli di atas maka dapat disimpulkan bahwa kalimat adalah susunan kata yang memiliki kesatuan bentuk untuk dalam struktur terkecil yang memiliki makna lengkap baik dari penuturan secara lisan maupun tertulis. Jadi dengan adanya sebuah kalimat yang minimal berisi subjek dan predikat kita dapat memahami sebuah makna, sehingga bisa berkomunikasi.

Tiap kata atau frase dalam kalimat mempunyai fungsi yang mengaitkannya dengan kata atau frase lain yang ada dalam kalimat tersebut. Fungsi disini diberi pengertian hubungan saling ketergantungan antara unsur-unsur dari suatu perangkat sedemikian rupa sehingga perangkat itu merupakan keutuhandan membentuk sebuah struktur (Kridalaksana: 2002). Fungsi itu bersifat sintaksis, artinya berkaitan dengan urutan kata atau frase dalam kalimat. Fungsi sintaksis utama dalam bahasa adalah subjek, predikat, objek, pelengkap dan keterangan. Unsur-unsur tersebut berada terdapat dalam sebuah kalimat. Akan tetapi, kelima unsur tersebut memang tidak selalu bersama-sama ada dalam suatu kalimat.

Berikut jenis dari unsur-unsur kalimat:

1. Subjek (S)

Subjek merupakan hal yang sangat penting dalam sebuah kalimat sebagai unsur pokok yang mendampingi predikat. Fungsinya untuk menandai apa yang dinyatakan. Dengan adanya gambaran subjek, kalimat yang dihasilkan dapat terpelihara strukturnya.

Ciri-ciri subjek yaitu:

1) Tentangnya diberikan sesuatu.

2) Dibentuk dengan kata benda atau sesuatu yang dibendakan.

3) Dapat bertanya dengan kata tanya apa atau siapa dihadapan predikat.

Contoh, Juanda memelihara binatang langka

Siapa memelihara?

Jawab:

Juanda (maka juanda adalah S sedangkan memelihara adalah P).

2. Predikat (P)

Predikat secara khusus menjelaskan atau menggambarkan keterangan subjek. Fungsi predikat dapat dicari dengan menanyakan mengapa. Predikat dapat berupa kata kerja, kata benda, kata sifat dan kata depan. Predikat terbagi dua yaitu predikat verbal (predikat yang terdiri dari kata kerja, biasanya menyatakan tindakan atau perbuatan yang dilakukan oleh suatu objek) dan predikat nominal (predikat yang terdiri dari kata selain dari kata kerja). 
Ciri-ciri predikat yaitu:

1) Penunjuk aspek: sudah, sedang, akan, yang selalu didepan objek.

2) Kata kerja bantu: boleh, harus, dapat.

3) Kata penunjuk modal: mungkin, seharusnya, jangan-jangan.

4) Beberapa keterangan lain: bukan, justru, memang, yang biasnya terletak diantara subjek dan predikat.

5) Kata kerja kopula: ialah, adalah, merupakan, menjadi. Kopula mengandung pengertian merangkaiakan predikat nominal dengan subjeknya, khususnya frase benda-frase benda.

3. Objek (O)

Objek menunjuk kepada tujuan kalimat atau kepada apa kalimat itu ditujukan. Objek hanya memiliki tempat dibelakang predikat. Atau lebih jelasnya untuk melengkapi fungsi predikat. Fungsi objek dapat berubah menjadi subjek akibat pemasifan kalimat. Objek terbagi menjadi dua yaitu objek penderita yaitu objek yang dikenai perbuatan (selalu melekat pada kalimat aktif) dan objek pelaku yaitu objek yang melakukan perbuatan (selalu melekat pada kalimat pasif).

Ciri-ciri objek yaitu:

1) Objek selalu diletakkan setelah predikat.

2) Objek berupa nomina atau frase nomina.

3) Objek pada kalimat aktif transitif akan menjadi subjek jika kalimat itu dipasifkan. Perbuatan dari aktif ke pasif ditandai dengan perubahan unsur objek dalam kalimat aktif menjadi subjek dalam kalimat pasif yang disertai dengan perubahan bentuk verba predikatnya.

4. Pelengkap (Pel)

Pelengkap meiliki fungsi untuk melengkapi predikat. Sama halnya dengan objek, tetapi fungsi yang satu ini tidak memiliki fungsi khusus pada saat pemasifan kalimat.

Ciri-ciri pelengkap yaitu:

1) Dibelakang predikat.

2) Hasil jawaban dari predikat dengan pertanyaan apa.

Contohnya:

Diah mengirimi saya buku baru.

5. Keterangan $(\mathrm{K})$

Keterangan merupakan fungsi sintaksis yang paling beragam dan paling mudah berpindah letaknya. Keterangan dapat berada di awal, akhir, dan bahkan di tengah kalimat(Putrayasa, 2007:64-97). Keterangan digunakan sebagai unsur perluasan kalimat yang menjelaskan lebih terperinci apa yang dimaksud oleh kalimat. Keterangan memiliki beberapa jenis seperti keterangan waktu, keterangan cara, keterangan penyebab, keterangan tujuan, keterangan aposisi (penjelas kata benda), keterangan tambahan, keterangan pewatas (pembatas kata benda), keterangan penyerta, keterangan alat, keterangan similatif (kesetaraan), keterangan kesalingan (perbuatan silih berganti) dan lainnya.

Contoh:

Sekretaris itu mengambilkan atasannya air minum dari kulkas (keterangan tempat). 


\section{Metode}

Penelitian ini yakni penelitian kualitatif, sebab mengenakan pendekatan kualitatif yang hasil temuannya tidak diperoleh lewat prosedur statistik ataupun wujud ikatan yang lain. Dalam penelitian kualitatif, instrumen utama penelitian yakni pepenelitian itu sendiri yang terjun ke lapangan sertaberusaha sendiri mengumpulkan informasi yang setelah itu diucap selaku informasi kualitattif.Informasi dalam penelitianyakni berbentuk informasi tertulis ialah, kalimat- kalimat pribahasaindonsia.

Ada pula menurut Markhamah (2009) Sumber informasi berbentuk informasi tertulis, sehingga sumber informasi dalam penelitian yakni diperoleh dari novel kumpulan pribahasa, di peroleh dari Kusnadi Wasrie, Moh (2014) Metode pengumpulan informasi yang digunakan dalam penelitianyakni metode pustaka, ikuti, sertacatat. Informasi diperoleh dalam wujud tulisan yang berbentuk kalimat sertakata yang wajib dibaca sertadicatat. Sehabis terkumpul, setelah itu informasi dianalisis bersumber pada rumusan permasalahan yang terdapat dalam penelitian

Metode analisis data yang digunakan yakni dengan mengenakan metode pasertadengan metode dasar pilah faktor penentu( PUP) sertacara agih. Metode Pasertasering pula diucap metode bukti diri yakni metode yang dipakai buat mengkaji ataupun memastikan bukti diri satuan lingual penentu dengan mengenakan perlengkapan penentu yang terletak di luar bahasa, terlepas dari bahasa, sertatidak jadi bagian dari bahasa yang bersangkutan( Sudaryanto 1993). Metode pada mempunyai metode dasar yang diucap dengan metode dasar pilah faktor penentu( PUP).

alat-alat yang akan digunakan adalah bahasa itu sendiri merupakan metode agih. Alat-alat itu sendiri cara kerjanya melalui faktor-faktor dari bahasa itu untuk mencapai target penelitiannya misalnya kata yang dibagi ke dalam kata preposisi, kata ingkat serta kata adverbia, sintaksis dibagi kedalam subjek dalam kalimat, objek serta predikat. Silabe kata, klausa, dan sebagainya.

\section{Hasil}

Pada bab ini hendak disajikan hasil penelitian sertapembahasan menimpa analisis wujud fungsional kalimat pribahasa indonsia yang sudah dicoba. Sebagian pribahasa yakni perumpamaan ialah perbandingan arti yang sangat jelas sebab dia didahului oleh perkataan seolah- olah, ibarat, bak, semacam, laksana, berbagai, bagai sertaumpama.Penjelasan deskripsi hasil penelitian terhadap wujud fungsional kalimat pribahasaindonsia yang diperoleh dari hasil penelitian 
1. Air tenang menghanyutkan

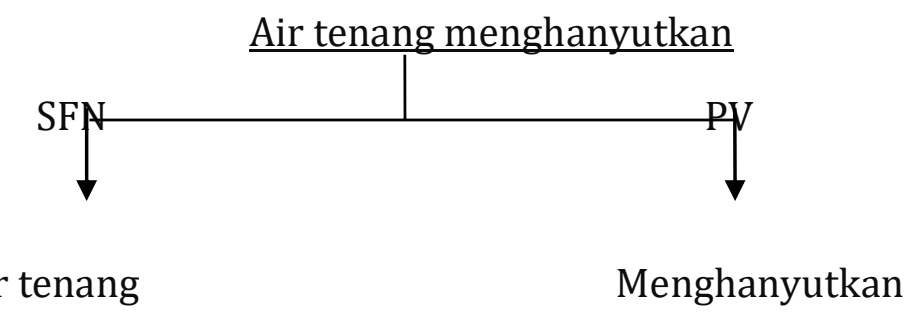

Pada kalimat di atas jika diliat kata "Air" tergolong kedalam kategori subjek (S), sedangkat pada kata selanjutnya "menghanyutkan" tergolong katergori predikat (P). Pada subjek (S) "air" dalam kalimat termasuk frasa nomina, sedangkan predikat (P) "menghayutkan" dalam kalimat termasuk verba.

2. Seperti katak dalam tempurung

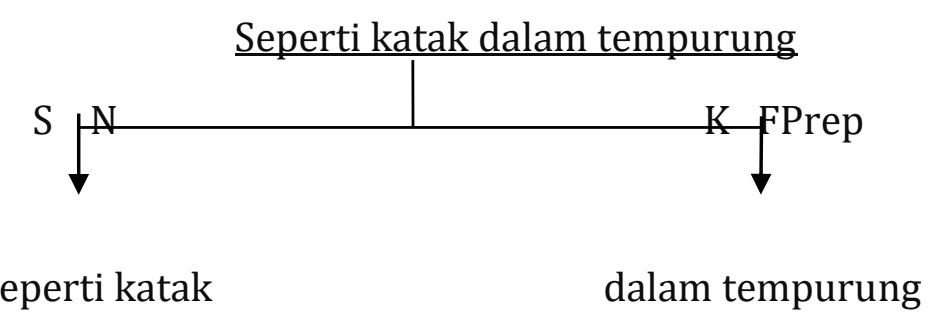

Pada kalimat di atas jika diliat kata "katak" tergolong kedalam kategori subjek (S), sedangkat pada kata selanjutnya "tempurung" tergolong katergori keterangan (K). Pada subjek (S) "katak" dalam kalimat termasuk nomina (B), sedangkan keterangan (K) "tempurung" dalam kalimat termasuk frasa proposisi.

3. Air susu dibalas air tuba

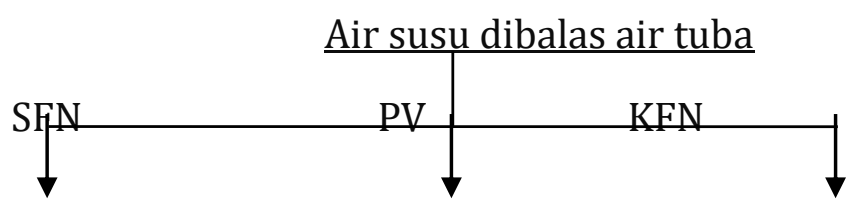

Air susu dibalas air tuba

Pada kalimat di atas jika diliat kata "air susu" tergolong kedalam kategori subjek (S), kata "dibalas" tergolong ke dalam kategori predikat (P), sedangkan pada kata selanjutnya "air tuba" tergolong katergori keterangan (K). Pada subjek (S) "air susu" dalam kalimat termasuk nomina (B), predikat "dibalas" dalam kalimat termasuk verba $(\mathrm{V})$, sedangkan keterangan $(\mathrm{K})$ "air tuba" dalam kalimat termasuk frasa nomina.

4. Menabur biji ke atas batu




Pada kalimat di atas jika diliat kata "biji" tergolong kedalam kategori subjek (S), kata "menabur" tergolong ke dalam kategori predikat (P), sedangkan pada kata selanjutnya "ke atas batu" tergolong katergori keterangan (K). Pada subjek (S) "biji" dalam kalimat termasuk nomina (B), predikat "menabur" dalam kalimat termasuk verba $(\mathrm{V})$, sedangkan keterangan (K) "ke atas batu" dalam kalimat termasuk frasa preposisi.

5. Seperti rusa masuk kampung

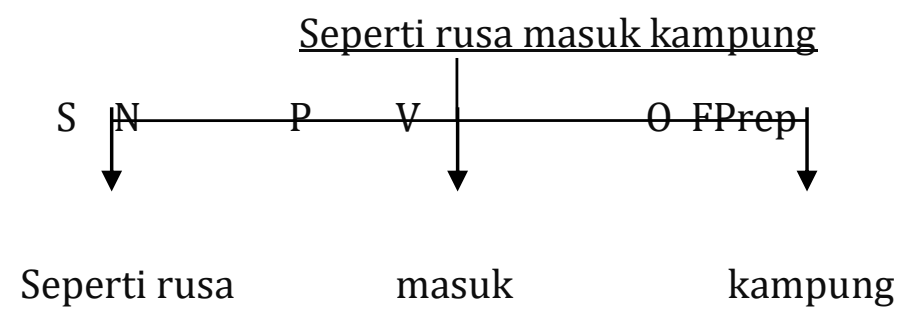

Pada kalimat di atas jika diliat kata "seperti rusa" tergolong kedalam kategori subjek (S), kata "masuk" tergolong ke dalam kategori predikat (P), sedangkan pada kata selanjutnya "kampung" tergolong katergori objek (O). Pada subjek (S) "seperti rusa" dalam kalimat termasuk nomina (B), predikat "masuk" dalam kalimat termasuk verba (V), sedangkan objek (0) "kampung" dalam kalimat termasuk frasa preposisi.

6. Ada udang di balik batu

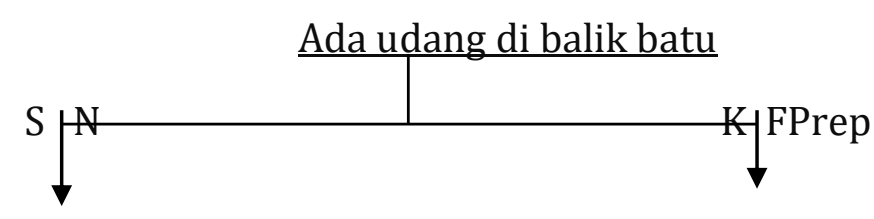

Ada udang

di balik batu

Pada kalimat di atas jika diliat kata "udang" tergolong kedalam kategori subjek (S), sedangkan pada kata selanjutnya "di balik batu" tergolong katergori keterangan (K). Pada subjek (S) "udang" dalam kalimat termasuk nomina (B), sedangkan keterangan (K) "di balik batu" dalam kalimat termasuk frasa preposisi.

7. Bagai pinang dibelah dua

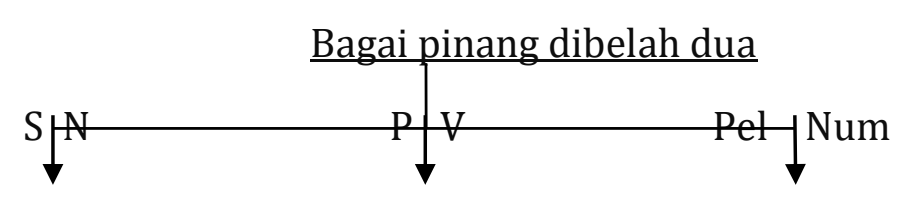

Bagai pinang dibelah

dua

Pada kalimat di atas jika diliat kata "bagai pinang" tergolong kedalam kategori subjek (S), kata "dibelah" tergolong ke dalam kategori predikat (P), sedangkan pada kata selanjutnya "dua" tergolong katergori pelengkap (P). Pada subjek (S) "bagai pinang" dalam kalimat termasuk nomina $(\mathrm{N})$, predikat "dibelah" dalam kalimat termasuk verba (V), sedangkan pelengkap (P) "kampung" dalam kalimat termasuk numerelia atau kata bilangan. 
8. Mencari jarum dalam jerami

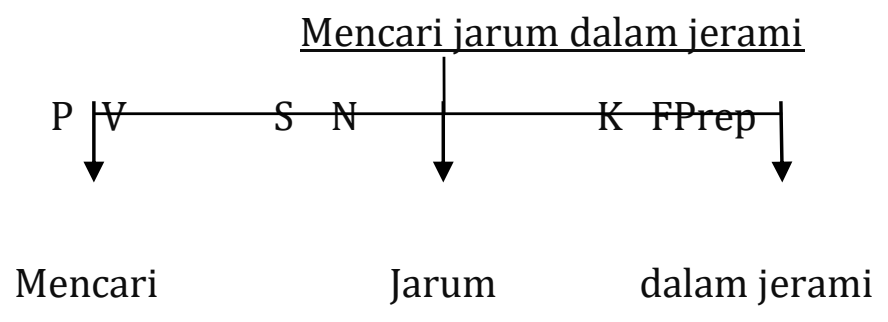

Pada kalimat di atas jika diliat kata "jarum" tergolong kedalam kategori subjek (S), kata "mencari" tergolong ke dalam kategori predikat (P), sedangkan pada kata selanjutnya "dalam jemari" tergolong katergori keterangan (K). Pada subjek (S) "jarum" dalam kalimat termasuk nomina $(\mathrm{N})$, predikat "mencari" dalam kalimat termasuk verba $(\mathrm{V})$, sedangkan keterangan (K) "dalam jerami” dalam kalimat termasuk frasa preposisi.

9. Bagai cacing kepanasan

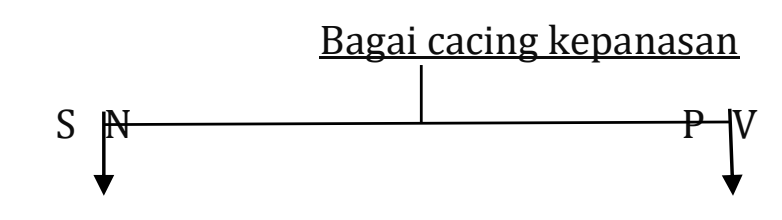

Bagai cacing kepanasan

Pada kalimat di atas jika diliat kata "bagai" tergolong kedalam kategori subjek (S), kata "kepanasan" tergolong ke dalam kategori predikat (P). Pada subjek (S) "jarum" dalam kalimat termasuk nomina (N), predikat "mencari" dalam kalimat termasuk verba (V).

10. Memancing di air keruh

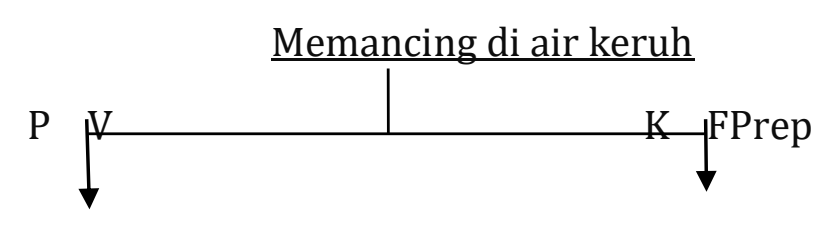

Memancing di air keruh

Pada kalimat di atas jika diliat kata "memancing" tergolong ke dalam kategori predikat (P), sedangkan pada kata selanjutnya "di air keruh" tergolong katergori keterangan (K). Pada predikat "memancing" dalam kalimat termasuk verba (V), sedangkan keterangan (K) "di air keruh" dalam kalimat termasuk frasa preposisi.

11. Bagai air di daun talas

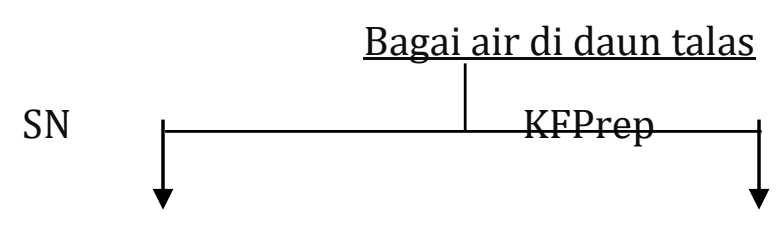

Bagai air di daun talas 
Pada kalimat di atas jika diliat kata "bagai air" tergolong kedalam kategori subjek $(\mathrm{S})$, sedangkan pada kata selanjutnya "daun talas" tergolong katergori keterangan (K). Pada subjek (S) "bagai air" dalam kalimat termasuk nomina $(\mathrm{N})$, sedangkan keterangan (K) “dalam jerami” dalam kalimat termasuk frasa preposisi.

12. Pagar makan tanaman

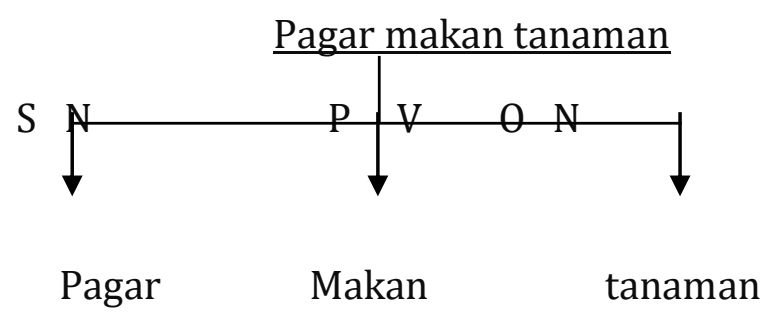

Pada kalimat di atas jika diliat kata "pagar" tergolong kedalam kategori subjek (S), kata "makan" tergolong ke dalam kategori predikat (P), sedangkan pada kata selanjutnya "tanaman" tergolong katergori objek (O). Pada subjek (S) "pagar" dalam kalimat termasuk nomina (N), predikat "makan" dalam kalimat termasuk verba (V), sedangkan Objel (O) "tanaman" dalam kalimat termasuk nomina.

13. Bagai burung dalam sangkar

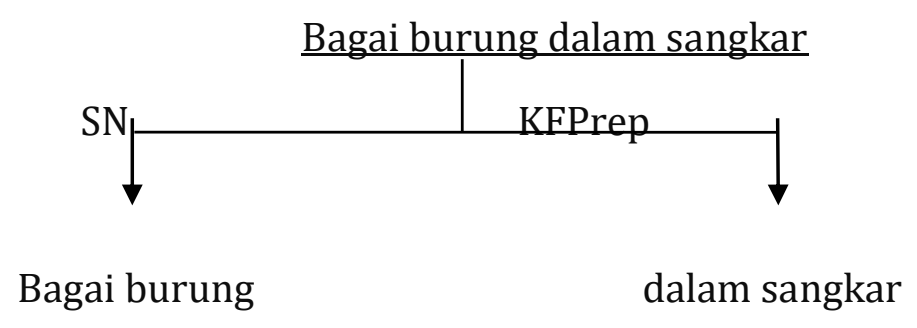

Pada kalimat di atas jika diliat kata "bagai burung" tergolong kedalam kategori subjek (S), sedangkan pada kata selanjutnya "dalam sangkar" tergolong katergori keterangan (K). Pada subjek (S) "bagai burung" dalam kalimat termasuk nomina (N), sedangkan keterangan (K) "dalam sangkar" dalam kalimat termasuk frasa preposisi.

14. Menjilat air liur

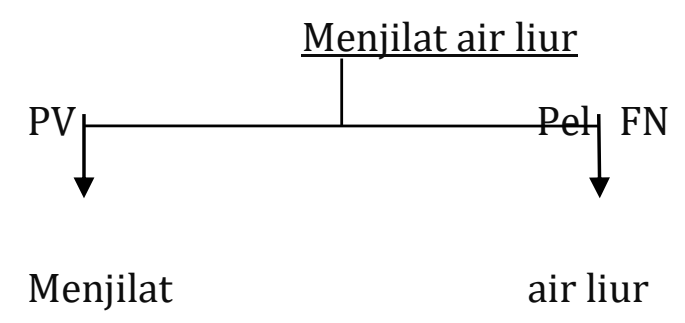

Pada kalimat di atas jika diliat kata "menjilat" tergolong ke dalam kategori predikat (P), sedangkan pada kata selanjutnya "air liur" tergolong katergori pelengkap (P). Pada predikat "mencari" dalam kalimat termasuk verba (V), sedangkan pelengkap (P) "dalam jerami" dalam kalimat termasuk frasa Nomina. 
15. Anjing menggonggong kafilah berlalu

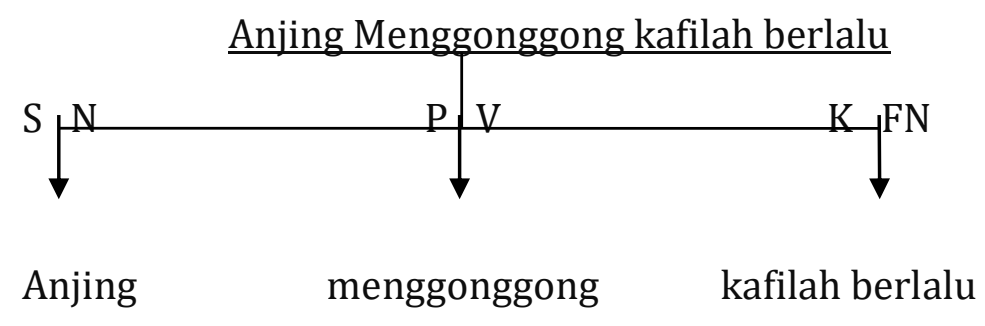

Pada kalimat di atas jika diliat kata "anjing" tergolong kedalam kategori subjek (S), kata "menggonggong" tergolong ke dalam kategori predikat (P), sedangkan pada kata selanjutnya "kafila berlalu" tergolong katergori keterangan (K). Pada subjek (S) "anjing" dalam kalimat termasuk nomina $(\mathrm{N})$, predikat "menggonggong" dalam kalimat termasuk verba (V), sedangkan keterangan (K) "kafila berlalu" dalam kalimat termasuk frasa nomina (FN).

16. Kucing pergi tikus menari

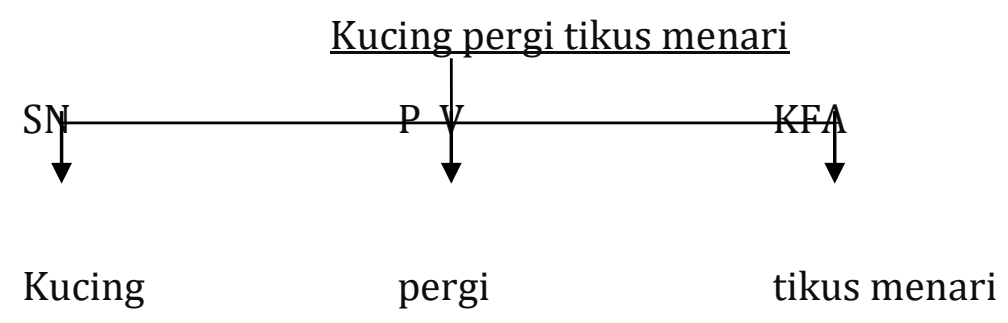

Pada kalimat di atas jika diliat kata "kucing” tergolong kedalam kategori subjek (S), kata "pergi" tergolong ke dalam kategori predikat (P), sedangkan pada kata selanjutnya "tikus menari" tergolong katergori keterangan (K). Pada subjek (S) "kucing" dalam kalimat termasuk nomina $(\mathrm{N})$, predikat "pergi" dalam kalimat termasuk verba $(\mathrm{V})$, sedangkan keterangan (K) "tikus menari" dalam kalimat termasuk frasa adjectival (FA).

17. Menggunting dalam lipatan

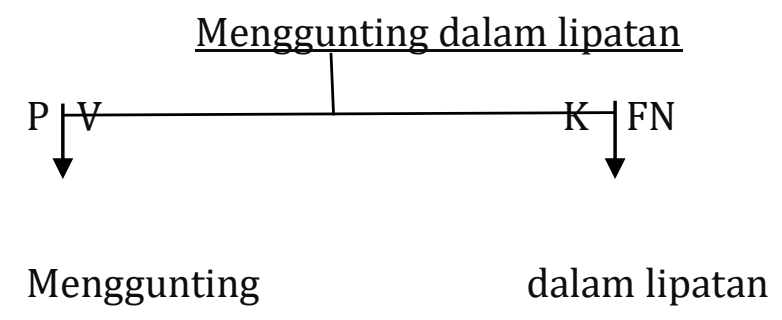

Pada kalimat di atas jika diliat kata "menggunting" tergolong ke dalam kategori predikat (P), sedangkan pada kata selanjutnya "dalam lipatan" tergolong katergori keterangan (K). Pada predikat "menggunting" dalam kalimat termasuk verba (V), sedangkan keterangan (K) "dalam lipatan" dalam kalimat termasuk frasa nomina (FN). 
18. Ayam bertelur di padi mati kelaparan

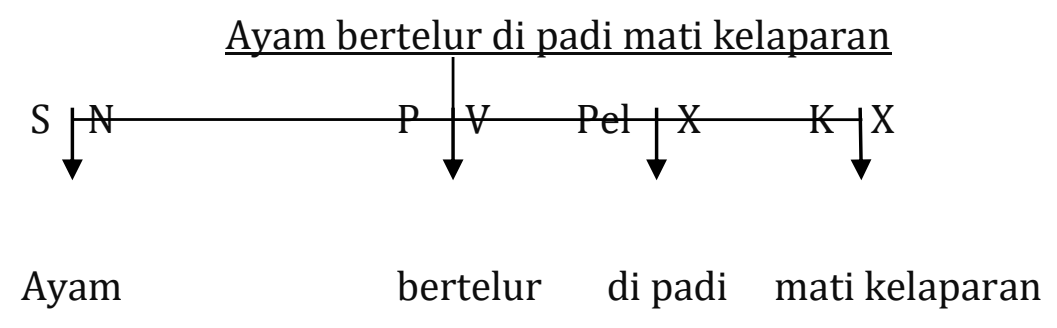

Pada kalimat di atas jika diliat kata "ayam" tergolong kedalam kategori subjek (S), kata "bertelus" tergolong ke dalam kategori predikat (P), kata " di padi" tergolong dalam kategori pelengkap (P), sedangkan pada kata selanjutnya "dalam jemari" tergolong katergori keterangan (K). Pada subjek (S) "ayam" dalam kalimat termasuk nomina $(\mathrm{N})$, predikat "bertelur" dalam kalimat termasuk verba (V), pelengkap (P) "di padi" dalam kalimat termasuk X, sedangkan keterangan $(\mathrm{K})$ "mati kelaparan" dalam kalimat termasuk frasa adjectiva.

19. Makan keringat orang

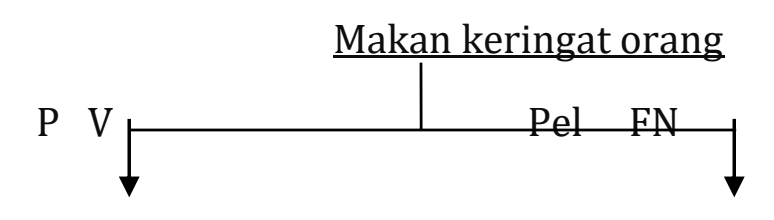

Makan keringat orang

Pada kalimat di atas jika diliat kata "makan" tergolong kedalam kategori subjek (S), sedangkan pada kata selanjutnya "keringat orang" tergolong katergori pelengkap (P). Pada subjek (S) "makan" dalam kalimat termasuk verba (V), sedangkan keterangan (K) "keringat orang" dalam kalimat termasuk frasa nomina (FN).

20. Lidah tak bertulang

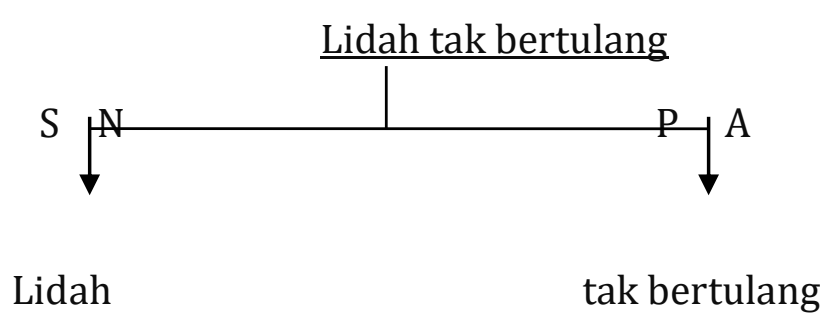

Pada kalimat di atas jika diliat kata "lidah" tergolong kedalam kategori subjek (S), sedangkan kata "tak bertulang" tergolong ke dalam kategori predikat (P). Pada subjek (S) "lidah" dalam kalimat termasuk nomina $(\mathrm{N})$, predikat "tak bertulang" dalam kalimat termasuk adjectiva (A. 
21. Berkelahi dalam mimpi

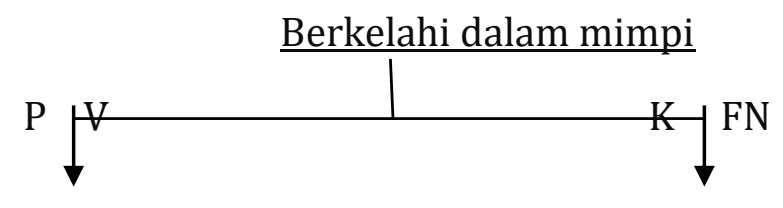

Berkelahi dalam mimpi

Pada kalimat di atas jika diliat kata "berkelahi" tergolong ke dalam kategori predikat (P), sedangkan pada kata selanjutnya "dalam mimpi" tergolong katergori keterangan (K). Pada predikat "berkelahi" dalam kalimat termasuk verba (V), sedangkan keterangan (K) "dalam mimpi" dalam kalimat termasuk frasa nomina (FN).

22. Membangunkan ular tidur

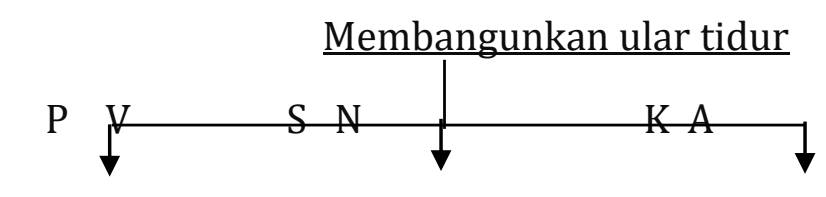

Membangunkan ular tidur

Pada kalimat di atas jika diliat kata "ular" tergolong kedalam kategori subjek (S), kata "membangunkan" tergolong ke dalam kategori predikat (P), sedangkan pada kata selanjutnya "tidur" tergolong katergori keterangan (K). Pada subjek (S) "ular" dalam kalimat termasuk nomina (N), predikat "membangunkan" dalam kalimat termasuk verba $(\mathrm{V})$, sedangkan keterangan $(\mathrm{K})$ "tidur" dalam kalimat termasuk frasa adjectiva.

23. Senjata makan tuan

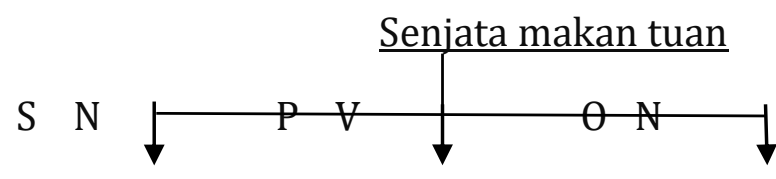

Senjata makan tuan

Pada kalimat di atas jika diliat kata "senjata" tergolong kedalam kategori subjek $(\mathrm{S})$, kata "makan" tergolong ke dalam kategori predikat (P), sedangkan pada kata selanjutnya "tuan" tergolong katergori objek (O). Pada subjek (S) "senjata" dalam kalimat termasuk nomina $(\mathrm{N})$, predikat "makan" dalam kalimat termasuk verba $(\mathrm{V})$, sedangkan objek (0) "tua" dalam kalimat termasuk nomina.

24. Musuh dalam selimut

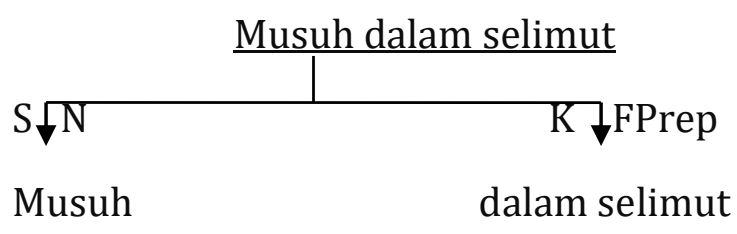


Pada kalimat di atas jika diliat kata "musuh" tergolong kedalam kategori subjek (S), sedangkan pada kata selanjutnya "dalam selimut" tergolong katergori keterangan (K). Pada subjek (S) "musuh" dalam kalimat termasuk nomina (N), sedangkan keterangan (K) "dalam selimut" dalam kalimat termasuk frasa preposisi.

25. Anak itu pandai mengecap

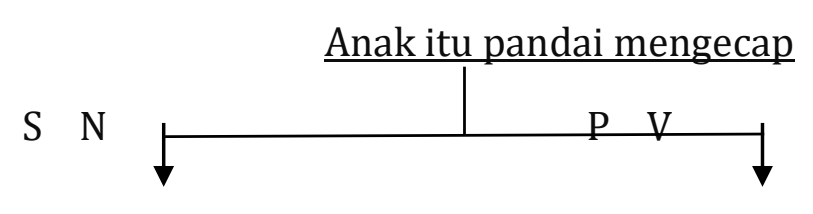

Anak itu

pandai mengecap

Pada kalimat di atas jika diliat kata "anak itu" tergolong kedalam kategori subjek (S), sedangkan kata "pandai mengecap" tergolong ke dalam kategori predikat (P). Pada subjek (S) "anak itu" dalam kalimat termasuk nomina $(\mathrm{N})$, sedangkan predikat "pandai mengecap" dalam kalimat termasuk verba (V).

26. Nasi sudah menjadi bubur

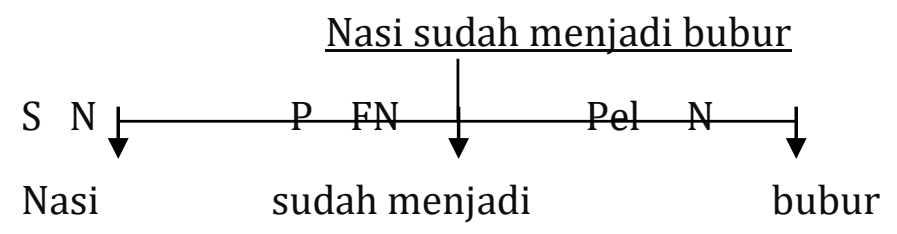

Pada kalimat di atas jika diliat kata "nasi" tergolong kedalam kategori subjek (S), kata "sudah menjadi" tergolong ke dalam kategori predikat (P), sedangkan pada kata selanjutnya "bubur" tergolong katergori pelengkap (pel). Pada subjek (S) "nasi" dalam kalimat termasuk nomina $(\mathrm{N})$, predikat "sudah menjadi" dalam kalimat termasuk frasa nomina (FN), sedangkan Pelengkap (Pel) "bubur" dalam kalimat termasuk nomina (N).

27. Membeli kucing dalam karung

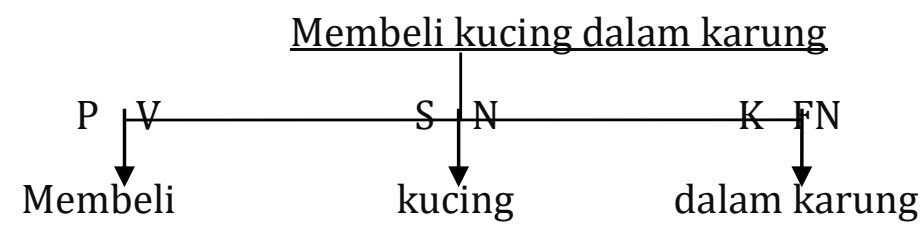

Pada kalimat di atas jika diliat kata "kucing" tergolong kedalam kategori subjek (S), kata "membeli" tergolong ke dalam kategori predikat (P), sedangkan pada kata selanjutnya "dalam karung" tergolong katergori keterangan (K). Pada subjek (S) "kucing" dalam kalimat termasuk nomina (N), predikat "membeli" dalam kalimat termasuk verba $(\mathrm{V})$, sedangkan keterangan $(\mathrm{K})$ "dalam karung" dalam kalimat termasuk frasa nomina (FN). 
28. Mengajar buaya berenang

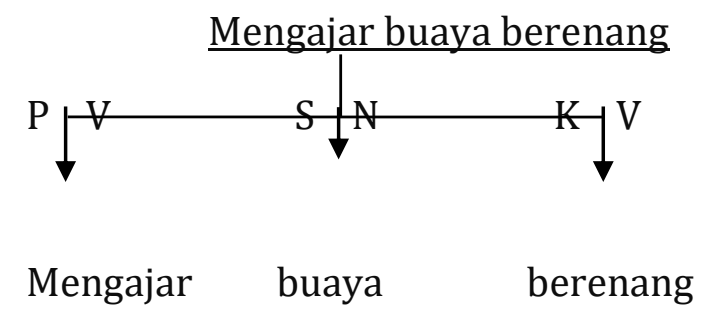

Pada kalimat di atas jika diliat kata "buaya” tergolong kedalam kategori subjek (S), kata "mengajar" tergolong ke dalam kategori predikat (P), sedangkan pada kata selanjutnya "berenang" tergolong katergori keterangan (K). Pada subjek (S) "buaya" dalam kalimat termasuk nomina $(\mathrm{N})$, predikat "mengajar" dalam kalimat termasuk verba $(\mathrm{V})$, sedangkan keterangan $(\mathrm{K})$ "berenang" dalam kalimat termasuk verba.

29. Seperti duri dalam daging

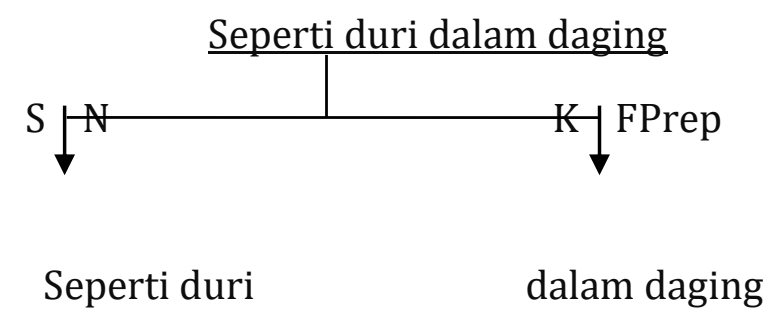

Pada kalimat di atas jika diliat kata "seperti duri" tergolong kedalam kategori subjek (S), sedangkan pada kata selanjutnya "dalam daging" tergolong katergori keterangan (K). Pada subjek (S) "seperti duri" dalam kalimat termasuk nomina (N), sedangkan keterangan $(\mathrm{K})$ "dalam daging" dalam kalimat termasuk frasa preposisi.

30. Gajah mati karena gadingnya

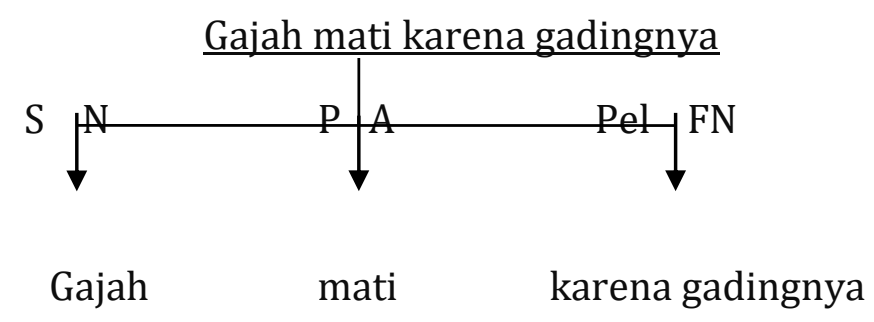

Pada kalimat di atas jika diliat kata "gajah" tergolong kedalam kategori subjek (S), kata "mati" tergolong ke dalam kategori predikat (P), sedangkan pada kata selanjutnya "karena gadingnya" tergolong katergori pelengkap (Pel). Pada subjek (S) "gajah" dalam kalimat termasuk nomina $(\mathrm{N})$, predikat "mati" dalam kalimat termasuk adjectiva $(\mathrm{A})$, sedangkan pelengkap (Pel) "karena gadingnya" dalam kalimat termasuk nomina $(\mathrm{N})$.

\section{Pembahasan}

Pada bagian pembahasan ini, akan dibahas tentang struktur fungsional kalimat peribahasa yang telah temukan dan diuraiakan pada bagian hasil penelitian. Berdasarkan uraian hasil penelitian pada tiga puluh kalimat peribahasa Indonesia, ditemukan struktur fungsional kalimat peribahasa dengan pola SP terdiri dari empat kalimat, pola SK terdiri dari enam kalimat, pola SPO terdiri dari tiga kalimat, pola SPK terdiri dari satu kalimat, 
pola PSK terdiri dari lima kalimat, pola PK terdiri dari tiga kalimat, pola SPPel terdiri dari lima kalimat, pola PPel terdiri dari dua kalimat, dan pola SPPelK terdiri dari satu kalimat

Berdasarkan hasil penelitian yang telah dilakukan, tidak ditemukan struktur kalimat peribahasa dengan pola SPOK. Pada kalimat peribahasa yang telah dianalisis, struktur fungsi yang selalu ada dalam kalimat peribahasa ialah fungsi $S$ (subjek) dan $P$ (predikat), dengan dominan kalimat didahului oleh fungsi S (subjek).

Seperti yang telah dijelaskan pada bab sebelumnya, bahwa struktur fungsional kalimat adalah susunan bangun kalimat yang terdiri atas unsur-unsur kalimat yang memiliki atau memduduki fungsi tertentu dalam suatu kalimat. Analisis fungsional di dasarkan atas fungsi S (subjek), P (predikat), O (objek), Pel (pelengkap), dan K (ketererangan). Unsur fungsional tidak selalu hadir bersamaan. Berikut ini pembahasan analisis yang dilakukan pada struktur fungsional kalimat peribahasa. Penelitian ini juga sejalan dengan dengan penelitian yang dilakukan sebelumnya oleh Fitria Nurkholis (2012) dengan judul Ragam dan Struktur Fungsional Kalimat pada Terjemahan Al-Quran Surah Al-Lail. Yang menyatakan bahwa kalimat-kalimat dalam terjemahan Al-Quran memiliki struktur yang tidak sejalan dengan struktur fungsional kalimat bahasa Indonesia yang lazimnya berstruktur SPOK. Selain itu, sebagian besar pola-pola kalimat pada peribahasa Indonesia fungsi pengisi fungsi $P$ (predikat) merupakan kata atau frasa yang berkategori V (verba) atau FV (frase verba)

\section{Simpulan}

Berdasarkan data dari hasil penelitian yang telah dipaparkan, beberapa pribahasa ditinjau dari segi linguistik sintaksis yakni dengan bentuk subjek+Predikat terdapat empat kalimat, bentuk subjek+keterangan terdapat enam kalimat, bentuk subjek+predikat+objek terdapat tiga kalimat, bentuk subjek+predikat+keterangan terdapat satu kalimat, bentuk predikat+subjek+keterangan terdapat lima kalimat, bentuk predikat+keterangan terdapat tiga kalimat, subjek+predikat+pelengkap terdapat dua kalimat, bentuk Subjek+predikat+pelengkap+keterangan terdapat satu kalimat.

\section{Ucapan Terima Kasih}

\section{Daftar Pustaka}

Arifin, Zainal dan Tasai. 2008. Cermat Berbahasa Indonesia. Jakarta: Akademika Pressindo.

Chaer, Abdul. 2007. Linguistik Umum. Jakarta: Rineka Cipta.

Chaer, Abdul. 2009. Sintaksis Bahasa Indonesia Pendekatan Proses. Jakarta: Rineka Cipta.

Hidayat, Taufiq. 2012."Analisis Struktur Fungsional dan Ragam Kalimat pada Terjemahan Surah An-Naba”. Skripsi: Surakarta: Universitas Muhammadiyah Surakarta.

Khairah. Miftahul dan Ridwan Sakura. 2015. Sintaksis Memahami Satuan Kalimat Perspektif Fungsi. Jakarta: Bumi Aksara. 
Kridalaksana, Harimurti. 2002. Struktur, Kategori, dan Fungsi dalam Teori Sintaksis. Jakarta: Universitas Katolik Atma Jaya.

Kusnadi Wasrie, Moh. 2014. Kumpulan Peribahasa. Jakarta: Lingkar Media.

Manaf, Ngusman Abdul. 2009. Sintaksis: Teori dan Terapannya dalam Bahasa Indonesia. Padang: Sukabina Press.

Markhamah. 2009. Ragam dan Analisis Kalimat Bahasa Indonesia. Surakarta: Muhammadiyah University Press.

Nur Azizah, Farida. 2010. "Ragam dan Struktur Fungsional Kalimat pada Terjemahan AlQuran Surah Luqman". Skripsi: Surakarta: Universitas Muhammadiyah Surakarta.

Nurkholis, Fitria. 2012. "Ragam dan Struktur Fungsional Kalimat pada Terjemahan AlQuran Surat Al-Lail”. Skripsi: Surakarta Universitas Muhammadiyah Surakarta.

Putrayasa, Ida Bagus. 2007. Analisis Kalimat: Fungsi, Kategori, dan Peran. Bandung: PT Refika Aditama.

Ramlan, M. 1996. Ilmu Bahasa Indonesia: Sintaksis. Yogyakarta: CV. Karyono.

Sudaryanto. 1993. Metode Linguistik: Metode dan Aneka Teknik Pengumpulan Data. Yogyakarta: Gadjah Mada University Press. 